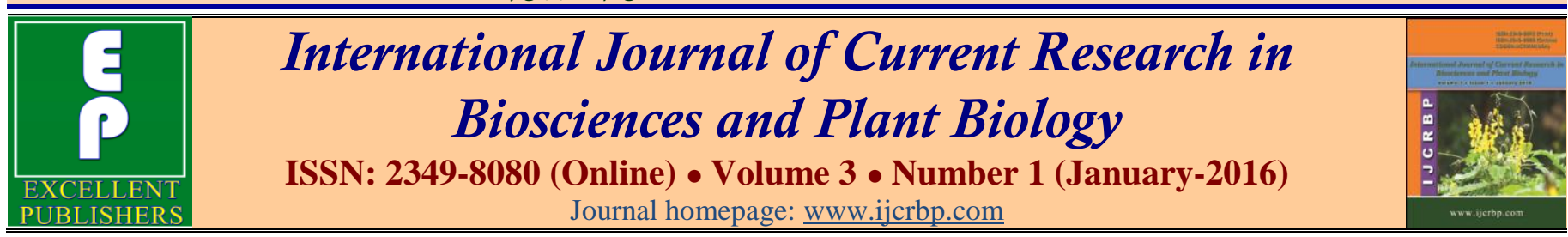

Original Research Article

doi: http://dx.doi.org/10.20546/ijcrbp.2016.301.002

\title{
Stem and Leaf Anatomy of Lantana camara L. - A Plant of the Verbenaceae Family
}

\author{
Rubaiyat Sharmin Sultana* \\ Department of Botany, University of Rajshahi, Rajshahi-6205, Bangladesh \\ *Corresponding author.
}

\section{Abstract}

The fresh hand sections of stem and leaf of Lantana camara L. were studied with light microscope, was intended to find out identical characteristics. Epidermis was the outermost covering layer of the stem section, was a single layer of compactly arranged by barrel-shaped parenchyma cells without intercellular spaces. Cortex was represented by several layers of loosely setup parenchyma cells with prominent intercellular spaces. Endodermis was the innermost layer of cortex, was prepared with barrel shaped cells. Xylem and phloem tissues were located upper and lower of meristematic cambium, respectively. The meristematic cambium was composed of 3 cells layers. Pith was the innermost part of the stem formed by a group of loosely constructed parenchyma cells with prominent intercellular spaces. Leaf blades presented uniseriate epidermis cells with thin periclinal walls and a relatively thick cuticle on the adaxial surface. The mesophyll was dorsiventral and having secretory idioblasts. It was composed with two layers of palisade parenchyma and three layers of spongy parenchyma. The vascular system is open, forming a flattened arch in the "V" shape with two accessory bundles located dorsally and groups of secretory idioblasts located laterally in the cortical parenchyma.
\end{abstract}

\section{Introduction}

Lantana camara L. belonging to the family Verbenaceae, is distributed in approximately 60 countries and is widely growing in the Asia-Pacific region, Australia, New Zealand, Central and South America, West Indies and Africa. It is an uneven evergreen shrub growing to $1.8 \mathrm{~m}$ high with square shaped stems with small prickles. Flowers are a mixture of cream, pink or orange numerous small rounded heads often in two colors, yellow and red, always attractive when they bloom (Sharma et al., 1988). L. camara is also used as herbal medicines. Leaf extracts of L. camara exhibit antimicrobial, fungicidal, insecticidal and nematicidal properties. Verbascoside, which possesses antimicrobial, immunosuppressive and antitumor activities, has been isolated from L. camara.

\section{Article Info}

Accepted: 07 December 2015

Available Online: 06 January 2016

\section{Keywords}

Anatomy

Idioblasts

Leaf

Lantana camara

Stem

Verbenaceae 
level, and often involves the sectioning of tissues and microscopy. Anatomical studies have much significance in different sectors of investigation. Studies on anatomy of plants can explain where, what, when and how chemical components are produced. The anatomical studied can be clarified the qualities of the wood properties. Anatomic studies have shown to be an important tool associated with taxonomic studies, mainly when there is no reproductive organ in the investigated sample (Solereder, 1908; Metcalfe and Chalk, 1950).

The limited number of plants of the Verbenaceae family had been undertaken in anatomical studies. The development and structure of pneumatophores were reported in Avicennia marina (Forsk.) Vierh (Purnobasuki and Suzuki, 2005). In this plant, responses in the anatomical changes of leaf were evaluated in various salinity conditions (Borkar et al., 2009; Ghowail et al., 1993). Robert et al. (2009) studied wood anatomy with vessel grouping, length and diameters in A. marina. The anatomical changes with environmental pollutions were reported in A. marina (Diab and Bolus, 2014; El-Tarabily and Youssef, 2010). A few numbers of studies on anatomy have been carried out in Lantana species. The leaf anatomy of two Lantana species ( $L$. camara and $L$. radula) has been carried out for understanding as an adaptive strategy (Dickison, 2000; Larcher, 2000). The structure, types and functions of the trichomes for adaptability of plants have already reported on some Lantana species (Solereder, 1908; Metcalfe and Chalk, 1950; Inamdar, 1969; Moura et al., 2005). The unicellular nonglandular trichomes observed in L. camara (Inamdar, 1969; Moura et al., 2005). The anatomical characteristics reports are not available on $L$. camara without leaf. The objective of the present study is to characterize the anatomy of the stems and leaves of L. camara, aiming to find characteristics that could contribute for recognition of identical characteristics.

\section{Materials and methods}

Naturally grown Lantana camara L. was collected from Botanical garden of Rajshahi University campus, Bangladesh. Healthy whole plants with stems, branches, leaves and roots were collected. The stem slices and whole leaves were separated and washed them through running tap water to remove dirt or soil. Free hand transverse sections were prepared from stems and leaves. For preparation of stem sections, stem slice was cut into thin sections with stainless steel blade by hand and all sections were put into water in a plastic Petri dish. For sectioning of leaf, the leaf slice holding a midrib was placed into a potato block and sections were cut thin with stainless steel blade by hand and all sections were put into water in a plastic Petri dish. Thin and uniform sections of stem and leaf were kept in $1 \%$ (w/v) safranin solution for a period of 20 minutes and rinsed with distilled water for 5 minutes. For fast green staining, safranin stained sections were dept in $0.05 \%(\mathrm{w} / \mathrm{v})$ fast green for 1 minute. The double stained sections were dehydrated in graded ethanol series $(60 \%, 70 \%, 80 \%$, $90 \%$ and $100 \%$ ) followed by two minutes changes. The dehydrated sections were kept in xylol for 2-3 seconds and placed on a slide and wait a while for drying. The stained sections were mounted with a clean cover slip by a drop of Canada balsam. Finally, slides kept on a hot plate at $45^{\circ} \mathrm{C}$ for two days until Canada balsam gets complete dry. The stained sections of stem and leaf were observed with light microscope and photographs were taken with digital camera.

\section{Results and discussion}

\section{Stem anatomy of $L$. camara}

Epidermis was the outermost covering layer of the stem of $L$. camara It was a single layer of compactly arranged by barrel-shaped parenchyma cells with slightly thick walled where intercellular spaces were absent. Epidermis showed the presence of projections called stem hairs (trichomes). Trichomes were non-glandular, conical type, presenting a large base and a thin extremity. These trichomes were also unicelullar, visually larger and presented a set of bulky epidermis cells arranged radially at the base (Fig. 1B). Hypodermis was a region lying immediately below the epidermis in the stem sections. It was characterized by a few layers of collenchyma cells with angular thickenings. The cells were compactly arranged without any intercellular spaces (Fig. 1B). Cortex is the major part of the stem represented by several layers of loosely arranged parenchyma cells and intercellular spaces were prominent (Fig. 1B).

Endodermis was the innermost layer of cortex corresponds to compactly arranged barrel shaped cells without any intercellular spaces showing wavy in appearance (Fig. 1B). Due to vascular plant, xylem and phloem were existed as conducting tissue. The phloem and xylem cells located at upper and lower of cambium layer, respectively. The cambium layer was distinguished with 3 cells layer. Pith was an innermost part of the stem formed by a group of loosely arranged parenchyma cells and intercellular spaces were prominent (Fig. 1B). The anatomical structure in the cross section of the stem was 
in agreement with the general characteristics of the members of the Verbenaceae. The anatomical characteristics of different plants of Verbenaceae were described (Metcalfe and Chalk, 1957).

\section{Leaf anatomy of L. camara}

Leaf showed common morphological characteristics in $L$. camara, such as simple leaf, complete with petiole and pubescent; opposite-decussate phyllotaxy, sharp acuminated top and serrated edge. The petioles of this species (Fig. 1A) were flat and convex on the adaxial and abaxial surfaces. The epidermis layer of leaves was uniseriate with regular size cells, was wrapped with a thick cuticle on the adaxial surface. The stomata occur in both surfaces, though they were rare in the adaxial surface. They were located at the same level as the other epidermal cells, in the form of complex diacytic and anomocytic stomata. Non-glandular trichomes were found scattered through the entire petiole and leaf blades (Fig.1C), are of the conical type, presenting a large base and a thin extremity, and ornamentations on the wall. These trichomes were unicelullar and presented a set of bulky epidermis cells arranged radially at the base (Fig. 1C). The trichomes were visually larger and more numerous (data not documented). Trichome frequency in the adaxial surface was double the value of the abaxial surface. The subepidermic portion is nearly three layers of collenchyma. The mesophyll is dorsiventral, with two layers of palisade parenchyma and three layers of spongy parenchyma, which is more compact and where secretory idioblasts were found (Fig. 1C). The vascular system was open, forming a flattened arch in the "V" shape with two accessory bundles located dorsally and groups of idioblasts located laterally in the cortical parenchyma (Fig. 1C).
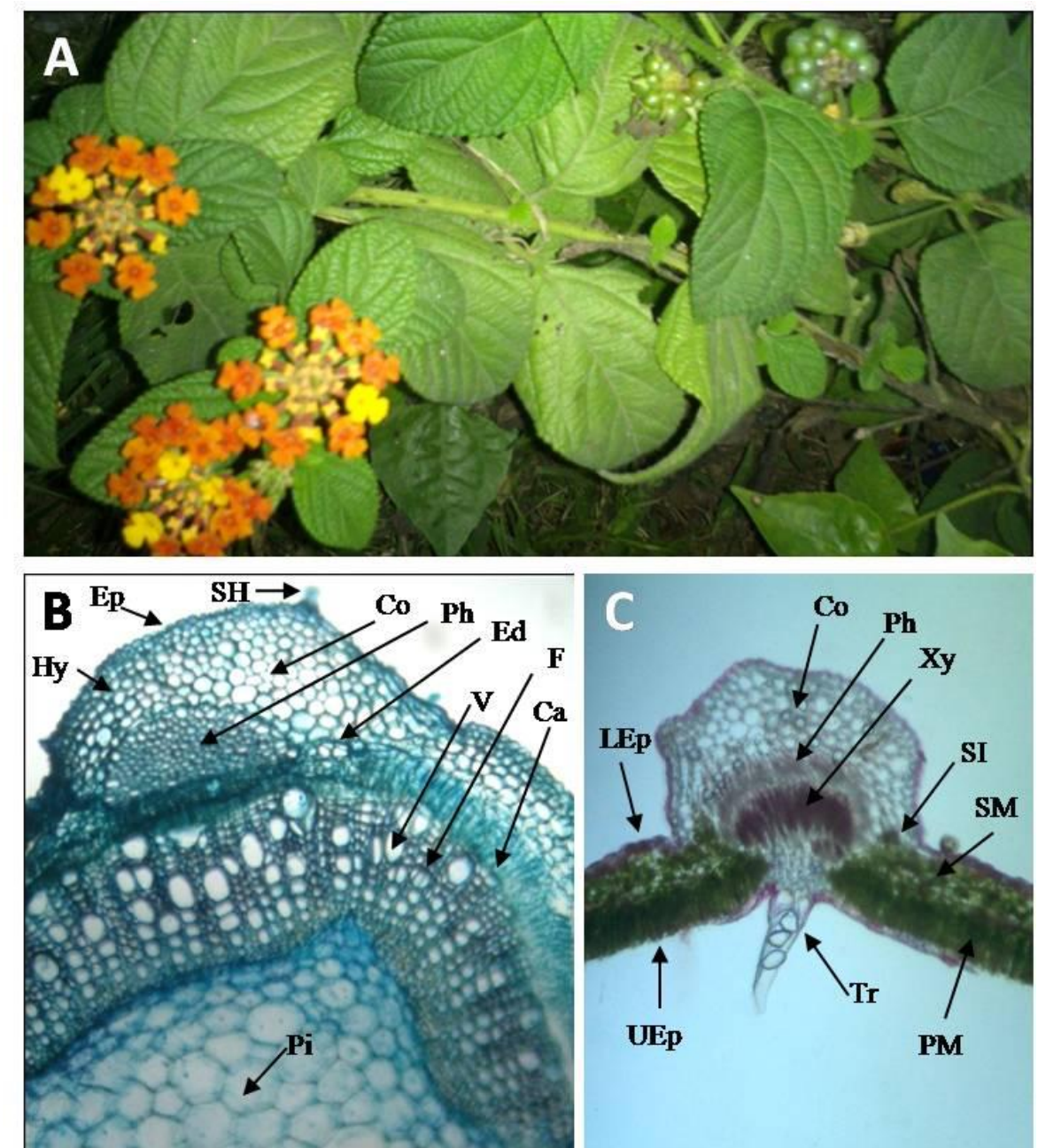

Fig. 1: Photographs of a plant and anatomy of leaf and stem of Lantana camara L. A) Plant bearing flowers, fruits and simple leaves. B) Stem anatomy. C) Leaf anatomy. SH: Stem hair, Ep: Epidermis, Hy: Hypodermis, Co: Cortex, Ph: Phloem, Ca: Cambium, V: Vessel, F: Fiber, Ed: Endodermis, Pi: Pith, LEp: Lower Epidermis, UEp: Upper Epidermis, SI: Secretory idioblasts, SM: Spongy Mesophyll, PM: Palisade Mesophyll, Tr: Trichome. 
The thick cuticle on the adaxial surface of the L. camara species must be an important characteristic for protection. It has been interpreted as an adaptive strategy in many plants (Dickison, 2000; Larcher, 2000). The cuticle recovers the epidermis of the plant and acts as an interface between the inside and outside of the organism (Bukovac et al., 1990) and must be considered in the interventions aiming at the chemical control of plants (Procopio, 2003).

Stomata distribution is being amphistomatic, with a greater number of stomata in the abaxial surface of $L$. camara. The amphistomatic leaves generally present larger quantities of stomata in the epidermis of the abaxial surface (Greulach, 1973), to which it seems to be a preventive mechanism against photoinhibition, since the adaxial surface is more exposed to solar radiation, as most of the leaves are in the horizontal position (Smith et al., 1998). Stomata on two leaf surfaces characterized in some species of the Verbenaceae family (Metcalfe and Chalk, 1950; Inamdar, 1969) and are ecologically less variable characters (Dilcher, 1974).

Trichomes, particularly the secretory ones, are considered important tools for taxonomy (Solereder, 1908; Metcalfe and Chalk, 1950; Fahn, 1979; Theobald et al., 1979). The glandular and non-glandular trichomes are distributed widely in the Verbenaceae family (Solereder, 1908; Metcalfe and Chalk, 1950) including many Lantana species (Solereder, 1908; Metcalfe and Chalk, 1950; Inamdar, 1969; Moura et al., 2005). The unicellular nonglandular trichomes observed in $L$. camara in the present study, similar statement reported in this plant earlier (Inamdar, 1969; Moura et al., 2005).

The largest frequency of the trichomes in the adaxial surface of $L$. camara can be related to several factors such as protection against excessive radiation and high temperatures, as reported in the literature (Valkama et al., 2003). However, in most cases, the true ecological function of the trichomes has not been supported by experimental data (Werker, 2000). The penetration of herbicides in the plant tissues is essential for the effective chemical control of weed (Procopio, 2003). The anatomical characteristics practically determine the ease with which these products can be absorbed (Hess and Falk, 1990). Trichomes in the leaf surface can intercept pulverized drops, preventing these from reaching the epidermis. The efficiency of herbicide absorption by the trichomes and their translocation to the epidermal cells are still partially unknown (Hess and Falk, 1990). However, the absorption of these substances can in part take place through the trichomes (Hull, 1970). Some authors consider that trichomes, especially the nonglandular types, are an efficient point for the penetration of herbicides in the plant tissue. Hess and Falk (1990) observed the negative relation between herbicide adherence in trichomes and the efficiency of these products. Thus, the high frequency of non-glandular trichomes in the adaxial surface of $L$. camara would be advantageous for the species when undergoing chemical control strategies, which are important distinctive characteristics for this species.

The dorsiventral arrangement in mesophyll observed in L. camara, is common characteristic in plants of the Verbenaceae family (Metcalfe and Chalk, 1950). Existing secretory idioblasts in L. camara would be an identical characteristic that did not show in other species of Lantana, as reported previously (Dickison, 2000). Thus, this characteristic could be a unique for this species, being important for taxonomic purposes.

\section{Conclusion}

The results presented in this study allowed the identification of stem and leaf characteristics. The groups of secretory idioblasts located in the mesophyll and the cortical parenchyma. It was possible to identify anatomical characteristics that allowed distinguishing one species of Lantana from the other, which is being important taxonomically. The present study will be helpful for further anatomical studies of plants of the Verbenaceae family.

\section{References}

Barreto, R.W., Evans, H.C., Ellison, C.A., 1995. The mycobiota of the weed Lantana camara in Brazil, with particular reference to biological control. Mycol. Res. 99(7), 769-782.

Borkar, M.U., Athalye, R.P., Goldin, Q., 2009. Salinity induced changes in the leaf anatomy of the mangrove Avicennia marina along the anthropogecically stressed tropical creek. J. Coastal Development 14(3), 191-201.

Bukovac, M.J., 199. Sorption of organic compounds by plant cuticles. Weed Sci. 38(3), 289-298.

Diab, E.A., Bolus, S.T., 2014. The Effect of Petroleum Pollutants on the Anatomical Features of Avicennia marina (Forssk.) Vierh. Intl. J. Sci. Res. 3(12), 25032515.

Dickison, W.C., 2000. Integrative Plant Anatomy. New York, Academic Press, New York. 534p.

Dilcher, D.L., 1974. Approaches to the identification of angiosperms leaf remains. Bot. Rev. 40, 1-157. 
El-Tarabily, K.A., Youssef, T., 2010. Enhancement of morphological, anatomical and physiological characteristics of seedlings of the mangrove Avicennia marina inoculated with a native phosphate-solubilizing isolate of Oceanobacillus picturae under greenhouse conditions. Plant Soil 332(1), 147-162.

Fahn, A., 1979. Secretory Tissues in Plants. Academic Press, London. 302p.

Ghowail, S.I., Abdel-Monem, A.M., El-Ghamry, W.M., Saber, N.E., 1993. Preliminary studies on the effect of different salinity levels on germination, growth and anatomy of mangrove (Avicennia marina). Tasks for Veget. Sci. 27, 237-244.

Greuach, V.A., 1973. Plant Function and Structure. Collier Macmillan, New York. 575p.

Hess, F.D., Falk, R.H., 1990. Herbicide deposition on leaf surfaces. Weed Sci. 38(3), 280-288.

Hull, H.M., 1970. Leaf structure as related to absorption of pesticides and other compounds. Res. Rev. 31(1), 1-155.

Inamdar, J.A., 1969. Epidermal structure and ontogeny of stomata in some Verbenaceae. Ann. Bot. 33(1), 55-66.

Jafri, S.M.H. and Ghafoor, A., 2005. Flora of Pakistan. http://www.efloras.org/ florataxon.Aspx.flora id $=5$ and taxon id $=10941$

Larcher, W., 2000. Ecofisiologia vegetal. São Carlos: Rima Artes e Textos, $531 \mathrm{p}$.

Metcalfe, C. R., Chalk, L., 1950. Anatomy of the Dicotyledons: Leaves, Stem and Wood in Relation to Taxonomy with Notes on Economic Uses. Oxford Clarendon Press, Oxford. 1500p.

Metcalfe, C.R. and Chalk, L., 1957. Anatomy of the Dicotyledons. II. Claredon Press, Oxford.

Moura, M.Z.D., Isalas, R.M.S., Soares, G.L.G., 2005. Ontogenesis of internal secretory cells in leaves of Lantana camara (Verbenaceae). Bot. J. Linn. Soc. 148(1), 427-431.
Procopio, S.O., 2003. Leaf Anatomical Studies in Weed Species Widely Common in Brazil. III - Galinsoga parviflora, Crotalaria incana, Conyza bonariensis and Ipomoea cairica. Planta Daninha 21(1), 1-9.

Purnobasuki, H., Suzuki, M., 2005. Functional anatomy of air conducting network on the pneumatophores of a mangrove plant, Avicennia marina (Forsk.) Vierh. Asian J. Plant Sci. 4(4), 334-347.

Robert, E.M.R., Koedam, N., Beeckman, H., Schmitz, N., 2009. A safe hydraulic architecture as wood anatomical explanation for the difference in distribution of the mangroves Avicennia and Rhizophora. Funct. Ecol. 23, 649-657.

Sharma, O.P., Makkar, H.P.S., Dawra, R.K., 1988. A review of the noxious plant Lantana camara. Toxicon 26(11), 975987.

Smith, W.K., Bell, D.T., Shephere, K.A., 1998. Associations between leaf structure, orientation and sunlight exposure in five western Australian communities. Am. J. Bot. 85(1), 56-63.

Solereder, H., 1908. Systematic Anatomy of the Dicotyledons. Oxford, Clarendon Press. p. 643.

Theobald, W.L., Krahulik, J.L., Rollins, R., 1979. Trichome description and classification. In: Anatomy of the dicotyledons, systematic anatomy of the leaf and stem (Eds.: Metcalfe C. R. and Chalk, L.). Oxford, Oxford Clarendon Press. pp. 40-53.

Valkama, E., 2003. Comparative analysis of leaf trichome structure and composition of epicuticular flavonoids in Finnish Birch species. Ann. Bot. 91(6), 643-655.

Werker, E., 2000. Trichome diversity and development. In: Advances in Botanical Research, Incorporating Advances in Plant Pathology - Plant Trichomes (Eds.: Hallahan, D.L., Gray, J.C., Callow, J. A.). Academic Press, San Diego. pp. 1-35.

\section{How to cite this article:}

Sultana, R.S., 2016. Stem and leaf anatomy of Lantana camara L. - A plant of the Verbenaceae family. Int. J. Curr. Res. Biosci. Plant Biol. 3(1), 27-31.

doi: http://dx.doi.org/10.20546/ijcrbp.2016.301.002 